This paper was published as one article of thirteen within a thematic issue of the Philosophical Transactions of the Royal Society A, Mathematical, Physical and Engineering

Sciences entitled 'The Anthropocene: a new epoch of geological time?' $13^{\text {th }}$ March 2011, Volume 369, Number 1938, pages 1056-1084. Please respect the copyright of the journal.

It is the authors' pre-publication version and minor differences may exist between it and the published version. For access to the published version please consult the Philosophical Transactions of the Royal Society A, (2011) 369, 1938, pages 1056-1084 doi:10.1098/rsta.2010.0296

\title{
Humans as major geological and geomorphological agents in the Anthropocene: the significance of artificial ground in Great Britain
}

\author{
SIMON J PRICE ${ }^{1, *}$, JONATHAN R FORD ${ }^{1}$, ANTHONY H COOPER ${ }^{1}$ AND \\ CATHERINE NEAL ${ }^{2}$ \\ ${ }^{1}$ British Geological Survey, Kingsley Dunham Centre, Keyworth, Nottingham, \\ Nottinghamshire, NG12 5GG
}

${ }^{2}$ Department of Archaeology, University of York, The King's Manor, York, YO1 7EP

Since the first prehistoric people started to dig for stone to make implements, rather than pick up loose material, humans have modified the landscape through excavation of rock and soil, generation of waste and creation of artificial ground. In Great Britain over the last 200 years people have excavated, moved and built up the equivalent of at least six times the volume of Ben Nevis. It is estimated that the worldwide deliberate annual shift of sediment by human activity is $57000 \mathrm{M}$ (million) tonnes and exceeds that of transport by rivers to the oceans (22 $000 \mathrm{M}$ tonnes) almost by a factor of three.

Humans sculpt and transform the landscape through the physical modification of the shape and properties of the ground. As such, humans are geological and geomorphological agents and the dominant factor in landscape evolution through settlement and widespread industrialisation and urbanisation. The most significant impact of this has been since the onset of the Industrial Revolution in the $18^{\text {th }}$ century, coincident with increased release of greenhouse gases to the atmosphere. The anthropogenic sedimentological record therefore provides a marker on which to characterise the Anthropocene.

Keywords: artificial ground; Anthropocene; anthropogenic activity; geomorphology; zone of human interaction; geological mapping; urban geoscience

*Author for correspondence (sprice@bgs.ac.uk)

One contribution of 12 to a Theme Issue 'Anthropocene: a new epoch of geological time’. 


\section{Introduction}

Since the first prehistoric people started to dig for stone to make implements, rather than pick up loose material, humans have modified the landscape through excavation of rock and soil, generation of waste and creation of artificial ground. It is estimated that the worldwide deliberate annual shift of material by human activity is $57000 \mathrm{M}$ tonnes and exceeds that of transport by rivers to the oceans (22 $000 \mathrm{M}$ tonnes) almost by a factor of three (Douglas \& Lawson 2001). Humans sculpt and transform the landscape through the physical modification of the shape and properties of the ground surface and subsurface. As such, humans are geological and geomorphological agents and the dominant factor in landscape evolution in the Anthropocene (Zalasiewicz et al. 2008; Zalasiewicz et al. 2010). The magnitude of impact (quantity and spatial extent) of material moved and its rate correlate with increasing population. The exploitation of the landscape and its subsurface to meet the needs of society is driven by changes in socioeconomic, technological, political and cultural parameters.

The geological and geomorphological impact of these changes is reflected in the deposition of made ground, removal of material through excavation, enhanced denudation through agricultural activity and the disruption of natural sediment transfer through dam construction for example. The former two processes represent the deliberate actions of humans to extract, transfer, re-use or discard rock, soil and man-made materials. This contrasts with the latter two processes where the impacts on sediments and sediment transfer are the unintentional consequence of anthropogenic processes where movement of sediment was not the primary objective. Anthropogenic processes where rock or soil is deliberately excavated, transported and deposited by people include: mining (subsurface and opencast), construction for settlement, industry, burial and defensive purposes, processing of metal ore, waste generation and canal, road and railway infrastructure construction. Unintentional activity relates to a combination of aeolian, hydrological and slope erosional processes related to soil loss and transport through agricultural modification of the landscape for pasture and arable land. Although both intentional and unintentional processes result in significant sedimentary markers on which the Anthropocene may be characterised, it is the deliberate, anthropogenic processes on which this paper focuses.

Widespread industrial activity and urbanization accelerated during the Industrial Revolution and is associated with increased input of carbon dioxide $\left(\mathrm{CO}_{2}\right)$ and methane $\left(\mathrm{CH}_{4}\right)$ into the atmosphere. It is proposed that this may represent a significant atmospheric marker defining the Anthropocene Epoch (Steffen et al. 2007; Zalasiewicz et al. 2008). However, the deliberate modification of the landscape to support human habitation and culture through resource exploitation, construction, demolition and deposition of wastes provides a sedimentological basis for defining the Anthropocene. Such sedimentological anthropogenic processes and their impacts are most significant during and after the Industrial Revolution in the late $18^{\text {th }}$ century (Figure 1). This period represents significant population growth, industrialisation and large scale exploitation of subsurface resources. This subsurface signature in the sedimentary record may provide a physical basis on which to characterise the Anthropocene. However, on a smaller scale, landscape transforming anthropogenic processes occurred before the $18^{\text {th }}$ century and the onset of widespread industrialisation.

Evidence for burning in upland areas and the discovery of middens, especially near the coasts of Great Britain in the Mesolithic, suggests landscape modification may have begun at this time. However, its spatial extent and the volume of material moved is likely to have been limited in Great Britain. Evidence of significant deliberate landscape modification is recognised as early as the Neolithic as people transformed their cultural way of life from hunter gatherers to farming and settlement. Trade of goods may have also taken place at this time reflecting early exploitation of subsurface resources of quality flint for tool making. 
Deliberate, landscape transformation through mineral exploitation, processing and waste generation gathered pace during the Bronze Age. It is around this time that transformation of the landscape increased and humans became geological and geomorphological agents through the deliberate removal, transport and placement of sediment. This deliberate, anthropogenic modification of the sedimentological record may provide a marker for the onset of the Anthropocene, although on this basis, its onset is likely to be diachronous.

The Roman occupation of Great Britain marked a time of population centralisation in towns and cities. Subsequent successive phases of urban expansion acted as the driver for increased landscape modification within these towns, cities and on the surrounding landscape which provided the resources to support their development. Although the timing of this is likely to be diachronous, it may be possible to define the Anthropocene on the basis of anthropogenic geological and geomorphological landscape transformation around this time.

Human activity and land use change has left an imprint above and below the land in the form of artificial ground. Artificial ground includes areas where material is known to have been placed by humans on the pre-existing natural land surface (including engineered fill) and areas where the pre-existing land surface is known to have been excavated. It can be a ground hazard, an archaeological heritage deposit and a potential mineral resource where economic conditions permit. Deposited in the shallow subsurface through historical and current anthropogenic activity, it forms part of a shallow zone of human interaction and has become part of the geological record from which the Anthropocene can be characterised. Due to its deposition in predominantly terrestrial environments, the long-term geological preservation potential of artificial ground is uncertain.

By understanding the physical impacts of historical and current changes in urban and rural land use, it may be possible to predict the resilience and future response of the Earth's shallow subsurface to environmental change.

\section{Humans as geological and geomorphological agents and the shallow zone of human interaction}

Landscape is a complex concept that can include topography, landform, an object, a way of seeing the world and an inhabited space (Thomas 2001). The modern landscape represents the surface expression of the underlying geology and the geological and anthropogenic processes that have transformed it. Landscape forming processes in Great Britain reflect a combination of natural and anthropogenic systems that remove, transport and emplace sediment. This flow of materials and their inclusion in the subsurface geological record is one of the defining processes that characterises the landscape that we see around us today.

Rapid population growth and the exploitation of the Earth's resources through urbanization, industrial and agricultural activity has led to humans becoming one of the most significant factors in the evolution of the Earth's landscape. As such, humans are a geological and geomorphological agent (Douglas \& Lawson 2001; Hooke 2000; Mulder 1996; Sherlock 1922; Wilkinson 2005). The impacts of anthropogenic transformation of the landscape through the transfer of quantities of rock and soil and the legacy it has left above and below the ground as artificial ground may be used as an indicator of human activity with which to characterise the Anthropocene (Zalasiewicz et al. 2008; Zalasiewicz et al. 2010).

While the ability of Homo sapiens to deliberately transform their environment is not unique in the animal kingdom, the magnitude of their impact (principally quantities of rock and soil transferred) is significant. Douglas \& Lawson (2001) estimate that $972 \mathrm{M}$ tonnes of earth material are deliberately moved by humans in Great Britain each year. This is comparable with the capacity of annelid earthworms for example to process soil after ingestion. Darwin, (1882) estimated that rates of soil processing in earthworms is as much as 
18.12 tonnes per acre per year (equivalent to an estimate of $991 \mathrm{M}$ tonnes per year in Great Britain).

In Great Britain, the geomorphological and geological resources of the Earth have provided the raw materials to support the expansion of human population. This includes the provision of raw materials for shelter, energy, technology and the space for the disposal of wastes. Population growth, industrial expansion and urbanization are therefore intimately linked to the direct impact of human activity on the landscape. Through history there have been pulses of intense landscape transformation taking place over short periods of time, punctuated by wars, economic depressions, famine and disease. Evidence of this legacy has the potential to be preserved as artificial ground either above or below the land surface.

Pre-Industrial (broadly pre $18^{\text {th }}$ century) human activity associated with the transition of human society towards settlement, agriculture and localised industrial activity, evolved in Great Britain from the Neolithic. Localised industrial and settlement activity included subsurface Neolithic flint workings at Grimes Graves in Norfolk (Oakley 1972), quarries for stone axe factories in Langdale (NW England), Bronze Age copper mining on the Great Orme (Williams 1995) and Parys Mountain Anglesey, North Wales

(Parys Underground Group 2010). The onset of such activities resulted in the extraction, transport and placement of rock and soil as artificial ground. Where people settled they also deposited wastes so that middens form part of the anthropogenic strata comprising artificial ground. These types of activities represented the first examples of humans contributing to the flow of geological material, and their role as geological and geomorphological agents in Great Britain.

The Iron Age saw the expansion of agricultural communities from their origins in the Neolithic, and an emerging culture working and smelting iron ore for weapons and implements and constructing defensive hill forts. There are numerous mining and smelting sites such as those in the Forest of Dean and Northamptonshire in England that show evidence of landscape excavation and waste deposition (Haselgrove 1999). This activity created a need for charcoal to smelt the ore, leading to deforestation and the start of human influence on soil erosion.

Roman Britain saw an increase in mineral production for commodities including copper, salt, coal and lead (Cooper 2002; Williams 1995). At the same time major building projects using large amounts of quarried rock and burnt lime for concrete were undertaken as Roman populations became centralised into urban centres forming the foundations of future towns and cities (Carver 1987). Such activity formed the first significant peak in the construction of the British built environment as towns and cities became the focus for manufacturing, processing and trade. Subsequent phases of urban growth, construction and demolition created an often thick 'urban deposit' including construction materials, foundations and wastes in middens. Urban growth rates fluctuated during the Anglo-Saxon, Anglo-Scandanavian and Medieval times, reaching a peak of new town construction in the $13^{\text {th }}$ century (Carver 1987), but mining continued for various metals and coal. During preIndustrial times, the relative scale of surface and subsurface impacts on the landscape may have been significant, but the geographic extent was generally limited (Table 1).

Wider geographic impacts were associated with intensive industrial activity, settlement and urbanization, beginning in the late $18^{\text {th }}$ century. Steffen and co-workers refer to this Era as the Industrial Era, Stage 1 of the Anthropocene, extending from ca. 1800 to 1945, (Steffen et al. 2007). They recognise this time as a major phase of human influence on the Earth System, significantly impacting the atmosphere through increased inputs of carbon dioxide $\left(\mathrm{CO}_{2}\right)$ and methane $\left(\mathrm{CH}_{4}\right)$. However, physical transformation of the landscape through anthropogenic modification of the surface and subsurface of the Earth was also significant. Mining activities, urbanization and waste production resulted in large magnitude 
impacts through increased volumes of earth material extracted, processed and deposited over increasingly short periods of time compared to the pre $18^{\text {th }}$ century. This resulted in the large scale creation of artificial ground. The intensity of human activity, resource exploitation, material consumption and landscape transformation varies though time, although the relative scale of impacts of that activity may be greater over shorter periods as populations expand (Figure 1). For example, coal production over the 350 years between 1500 and 1850 was around $2895 \mathrm{M}$ tonnes (Sherlock 1922). Later, an equivalent amount of coal was produced in only 23 years between 1860 and 1883. A coal mining peak in Great Britain between 1910 and 1920 witnessed the production of the same volume in just 10 years (Sherlock 1922) and BGS Mineral Statistics (British Geological Survey 2009).

Deposition of geological materials derived from anthropogenic activity includes the emplacement of construction materials and the disposal of wastes. While deposition may occur close to the source of extraction, construction of the built environment often requires the transport and net import of materials from a wide catchment. Major urban areas might therefore be thought of as sinks for the deposition of geological materials that are either directly won from the ground or processed for re-use in construction (e.g. manufacture of concrete and bricks). Anthropogenic activity including transport and use of construction material, can therefore create an urban 'deposit' through inflow of material into the built environment (Douglas \& Lawson 2001). Although centralised urban construction for residential, commercial and industrial purposes focuses deposition of transferred material as artificial ground, its impact on rural environments is also significant. Infrastructure and people in urban areas rely on resources transported in to them to sustain their growth. Transport of agricultural products and construction materials amongst others are required, along with the road, rail and canal transport routes to carry them either from other parts of Great Britain, or increasingly from international sources via ports and airports. Similarly, just as urban areas receive a net inflow of resources to support them, they are also net generators of waste materials. These materials may be buried in landfill sites or recycled and reused in construction where the 'sediment' is fit for that purpose. In all cases, the deposition of processed natural rock or soil raw materials results in the creation of artificial ground and constitutes an anthropogenic feature of the Anthropocene.

The political, socioeconomic and technological drivers that accelerated Britain's industrial growth transformed the pattern of human habitation in the $18^{\text {th }}$ and $19^{\text {th }}$ centuries. Previously, localised habitation and industry was generally restricted by the availability of energy sources such as water and wind. Industrialisation resulted in a rapid transformation to city living and centralized human occupation that began as far back as the Roman period. Globally, in 1890 approximately 200 million people lived in cities compared to approximately 3 billion in 2001 (Steffen et al. 2007). In the UK alone, nearly 80\% of people lived in an urban area in 2001 (Jeffries 2005).

It is estimated that by the Domesday survey of 1086, lowland Britain was already densely populated. Deforestation as a result of this meant that woodland comprised just 5\% of the landscape of eastern England and 15\% of England as a whole (Roberts 1998). The agricultural impacts of soil losses through processes such as tilling following tree clearances are significant. Some agricultural practices including tilling, mechanisation and increased field size increase the vulnerability of soils to aeolian and hydrological erosion. The erodibility of soils depends largely on the lithological composition of the soil. It is estimated that in the developed world, annual soil losses (denudation rate) from land classified as cropland are in the order of $1.0 \mathrm{~kg} / \mathrm{m}^{2}$ to $3.5 \mathrm{~kg} / \mathrm{m}^{2}$ from land classified as pasture (Hooke 2000). In some parts of northeastern and eastern England, landmass areas classified as arable are susceptible to soil erosion rates in the region of 2.1 to $4.4 \mathrm{~kg} / \mathrm{m}^{2}$ through aeolian erosion alone (Morgan 1985). 
Global anthropogenic denudation rates have exceeded those of natural, deep-time denudation since the first millennium (Wilkinson 2005). Global, deep-time denudation rates have fluctuated through the Phanerozoic, ranging from approximately 10 metres per million year $(\mathrm{m} / \mathrm{my})$ in the Middle Triassic to over $60 \mathrm{~m} / \mathrm{my}$ during the Pliocene with a mean average of $25 \mathrm{~m} / \mathrm{my}$ (Wilkinson 2005). When converted to geological timescales, denudation from anthropogenic cropland tillage alone is estimated to be in the order of 680 to $1400 \mathrm{~m} / \mathrm{my}$ in developed and undeveloped countries respectively (Pimental et al. 1995; Pimental \& Skidmore 1999). If the average denudation rate from agricultural activities is approximately $643 \mathrm{~m} / \mathrm{my}$ (Wilkinson 2005), then the rate of agricultural anthropogenic denudation is approximately 28 times that of the deep-time mean denudation rate.

Globally, Hooke (2000) estimates that in the year 2000, approximately 21 tonnes of rock and soil were moved per capita through combined agricultural and construction activities. The physical transformation of the Earth through human induced processes such as transfer of rock and soil or indirect erosion through tilling defines a shallow zone of human interaction in the geosphere. The end products of anthropogenic processes (either a sedimentary deposit or an erosional feature) provide a physical marker within the Anthropocene.

\section{Anthropogenic processes}

Evidence of anthropogenic processes is recorded in the landscape and its subsurface as either a constructional or erosional features. Rock, soil, anthropogenic (processed or manufactured) deposits or a mixture can be deposited and used in either a controlled engineered or an uncontrolled manner. Commonly, deposition results in a constructional landform, an engineered structure or, where the landform is poorly defined on the surface, a diffuse sedimentary deposit in the ground. Such deposits are referred to as made ground (see Section 4.2). Equally, anthropogenic processes may be expressed as excavations, representing natural material that has been removed through extraction. Such excavations are referred to as worked ground. The material flux associated with anthropogenic processes of removal, transport and deposition are similar to those geological processes of erosion, transport and deposition.

\subsection{Habitation and infrastructure}

The remains from habitation buried in the ground are recorded by archaeologists with a well defined historical chronology. However, for the past forty years or so, only the major features such as earthworks have been recorded by geologists as a part of artificial ground research. Many long-established cities have considerable thicknesses of artificial ground, caused by successive phases of habitation building on the remains of earlier development. This can result in made ground many metres high composed of building rubble and waste or, in large cities, widespread made ground that has a poorly defined margin and is very heterogeneous. This complexity of artificial ground beneath cities began with the onset of urban centralisation during the Roman period (Carver 1987) when buildings, transport infrastructure, irrigation and municipal waste tips were constructed. Successive phases of development have added, or in some cases reused and recycled this artificial ground, leaving a complex 'stratigraphy' of deposits including drains, middens, pits, cellars, foundations and trenches amongst other features. For example, in industrial Manchester and Salford, NW England, this has resulted in up to $10 \mathrm{~m}$ of artificial ground. In the heritage city of York, NE England, equivalent deposits reflecting over 2000 years of occupation, are up to $8 \mathrm{~m}$ thick (Holden et al. 2009). 
From an early age, the infrastructure that supports settlement and habitation included the construction of irrigation systems followed by canals, roads, railways and tunnels for transport. These have been excavated beneath the land surface, cut into the land or banked upon the natural ground surface, forming worked and made ground. From the Industrial Revolution onwards the scale of these activities has increased and the volumes of material now moved during construction are considerable. For example, the Channel Tunnel, linking Great Britain and mainland Europe, produced $20 \mathrm{M}$ tonnes of rock spoil, which was placed at the foot of Shakespeare Cliff, forming 40 ha (hectares) of new land at Samphire Hoe in Kent, SE England (Douglas \& Lawson 2001). The CrossRail railway scheme linking east and west London produced $5 \mathrm{M}$ tonnes of material from the rail link excavations which was shipped down river to form 600 ha of made ground at Wallasea Island, Essex (CrossRail 2010). Construction of an extension of the M6 motorway in the English Midlands, resulted in the movement of approximately $15 \mathrm{M}$ tonnes of material through excavation and embankment construction (The Motorway Archive 2010).

Currently the amount of material moved for road and infrastructure construction in Great Britain is probably about 155 M tonnes a year based on year 2000 figures (Douglas \& Lawson 2001). Historical made ground is most likely to be unengineered tipped fill. However, modern deposits for road and infrastructure construction are compacted and engineered for strength and performance; the majority of this built up material is of local or moderately local origin, though in coastal areas it may have been imported, sometimes as ship ballast from abroad. The volume of material moved for the construction of canals, railways, roads, motorways, tunnels and for building construction is significant. In 1922 Sherlock estimated the volume of material moved for the construction of canals, railways, tunnels, roads and building construction as $4507 \mathrm{M}$ cubic yards or about $3.5 \mathrm{~km}^{3}$ (Sherlock 1922). Since then, significant urban expansion and motorway construction has taken place, moving approximately $1500 \mathrm{M}$ tonnes in the last 10 years and possibly $11000 \mathrm{M}$ tonnes since 1922, a volume of around 8 or $9 \mathrm{~km}^{3}$.

\subsection{Natural resource exploitation}

The human need for minerals, energy and building materials has resulted in widespread mining and quarrying. The relative importance of cultural, socio-economic, political and environmental factors as drivers for the growth of populations and their use of natural resources changes through time. Mineral veins at the surface have been worked to leave opencast excavations in the landscape and spoil heaps as made ground. Quarrying, first for building stone, then later for brick clay, aggregate and cement manufacture, has left largescale areas of worked ground. Quarries for igneous and metamorphic rocks are visible in areas such as North Wales, the Lake District and the Midland Valley of Scotland. Technology such as hushing and ground sluicing, to locate mineral veins, is first seen in the Roman period, harnessing natural forces to aid production. To deliver the large quantities of water required to the mine head, large industrial aqueducts and hushing tanks were constructed. This system was used at the Roman gold mine Dolaucothi in southern Wales where widespread archaeological evidence for these processes has been recorded (Wilson 2002). Opencast mineral working, especially for coal and ironstone, has moved considerable volumes of overburden. This may reach 18 or 20 times the volume of the mineral extracted. In some areas of Great Britain, where the coal sequences come to surface, up to $20 \%$ of the land has been turned over in this manner. Some of these workings reach down to depths of 80 or more metres and the deepest, the former Westfield site in Scotland, to 215 metres (Durham Mining Museum 2010). 
Deeper working has resulted in collapses and open stopes creating subsidence that lowers the natural ground surface. This subsidence is effectively 'hidden' artificial ground. Underground coal workings were initially undertaken using pillar and stall extraction techniques leaving earlier random and then later regular patterns of galleries with supporting pillars. Where underground workings have been infilled for ground stabilisation, or where equipment and infrastructure have been left underground, artificial ground is created. Industrial impacts on the shallow subsurface are widespread and arise not only from the physical infrastructure associated with the mining industry but also from the chemical and biological processes which underpin these activities. The examination of $9 \mathrm{~m}$ deep alluvial deposits on the banks of the Ouse at North Street, York revealed the presence of lead contamination arising from relatively remote Yorkshire Dales mining activity between the 9th and 13th centuries AD. Contamination was sourced from mining and smelting activities and transported contaminants by the River Ouse. There were also local effects from consumption, including use, wear and disposal (Hudson-Edwards 1999).

Using BGS figures for extraction since 1850, the total UK mined (onshore and undersea) and opencast coal is around $24700 \mathrm{M}$ tonnes or a volume of around $19.5 \mathrm{~km}^{3}$ of extraction. The waste from this adds another $6800 \mathrm{M}$ tonnes with a solid volume of around $3.1 \mathrm{~km}^{3}$ and a bulked up volume of around $5 \mathrm{~km}^{3}$. UK production of iron ore from 1850 to 1973 (Figure 1) was about $1582 \mathrm{M}$ tonnes. A bulk density of $2.59 \mathrm{~g} / \mathrm{cc}$ suggests an extracted volume of about $0.6 \mathrm{~km}^{3}$ plus $1.8 \mathrm{~km}^{3}$ of overburden. A significant amount of the ore volume has been turned into furnace slag and waste tips. These are just a few indicators of the magnitude of impact and landscape modification by humans creating artificial ground and subsidence. Applying similar calculations to all of the major commodities listed in the BGS mineral statistics for the UK gives a total volume of around $38.5 \mathrm{~km}^{3}$ of material (mineral, overburden and waste) moved by humans for mineral extraction since 1850 . This is equivalent to moving more than four times the volume of Ben Nevis in the past 160 years.

From early in the $20^{\text {th }}$ century longwall mining of coal became the standard extraction technique made possible by technology allowing roof support and ventilation (Bell 2000). In the longwall workings, panels of coal were extracted between parallel tunnels dug out from a service or haulage tunnel. This technique left less of the resource underground, but caused largely predictable subsidence at the surface. The mechanised extraction also generated more waste than manual digging.

Some minerals such as salt are soluble and were originally gathered from natural brine springs. With industrialisation, pumping of the wild brine allowed large amounts of production. It also caused severe subsidence in places such as Northwich and Droitwich in central England (Cooper 2002). The brine run subsidence features can run for $10 \mathrm{~km}$ or so from the salt works pumping them. Many square kilometres of the Cheshire salt area, NW England, are affected by this sort of subsidence and similar features; brine extraction and subsidence also affects land near Preesall (Lancashire, NW England) and Teesside (NE England). Such features are now integral parts of the landscape. For example, lakes or 'meres' now occupy salt subsidence features in Cheshire.

Similarly, the areas and volumes of subsided land caused by coal mining are considerable. In Great Britain it is not uncommon for between one and three metres of subsidence to have occurred due to mining operations. Toll Bar near Doncaster, NE England is an example of this; a comparison of benchmarks here shows up to $3.1 \mathrm{~m}$ of subsidence between 1948 and 2007. Elsewhere up to $13 \mathrm{~m}$ of subsidence has occurred at Silverdale near Wigan, NW England (D Wilshaw pers comm). From mining literature (Bell et al. 2000; NCB 1975 ) it is likely that there is a range of values from $50 \%-90 \%$ of the mined volume manifesting itself as surface subsidence. BGS mineral figures for deep coal mining since 1900 (assumed to be mainly longwall mining) indicates $18151 \mathrm{M}$ tonnes of coal extraction. 
With a density of $1.26 \mathrm{~g} / \mathrm{cc}$ (DTI 2004) and a waste extraction of 35\% this equates with a surface subsidence volume of between 9.7 and $19.4 \mathrm{~km}^{3}$ depending on what percentage of subsidence manifests itself at the surface. It must be noted that a proportion of this subsidence will be under the sea.

\subsection{Natural resource processing and wastes}

Deep coal mining generates about 35\% waste which is deposited as spoil heaps that form amongst the most significant anthropogenic landforms in Great Britain. Information from Ordnance Survey maps shows some spoil heaps covering between half and one square kilometre (e.g. Gasgoinge Wood Mine, NE England), containing millions of tonnes of waste. Most mineral processing generates waste and some such as iron smelting and oil shale processing generate very large volumes compared with the end product. Artificial ground comprising furnace slag covers large areas around many British towns and cities. The form of these waste heaps varies from small, randomly tipped heaps near historical mines and smelters through more organised tips built out from mine or works railways or conveyors. Modern tips can extend over many hundreds of hectares, can be tens of metres high and, unlike their earlier counterparts, can be heavily engineered for stability. In coastal areas much of the waste material has been used for land reclamation (e.g. Teesside, NE England and Port Talbot, South Wales), where reclaimed land several kilometres across has been built up by furnace wastes and other spoil (Waters et al. 2005). The tonnages and volumes of waste products produced in the UK each year are very large, but some of the materials can be reused, often being re-deposited in the urban environment.

Domestic and industrial waste tips are a type of artificial ground and commonly occupy previously excavated holes in the ground or sit upon the ground if there are no convenient workings. For example, much of Ferrybridge Power Station's fly ash, in NE England is deposited in settling ponds constructed in the former sand and gravel pits of the Aire Valley, North Yorkshire. Old waste tips commonly fill quarries and small river valleys and were completely uncontrolled in their content (Dearman et al. 1977). Modern waste disposal sites by comparison are licensed and have facilities for the interception and removal of gas and leachate. In 1995, municipal and household waste was $25.89 \mathrm{M}$ tonnes and 88.6\% of this went to landfill (22.9 $\mathrm{M}$ tonnes) with only 6.4\% being recycled (Douglas \& Lawson 2001). By 2005/6 there were $35.1 \mathrm{M}$ tonnes of municipal waste, $64 \%$ (22.5M tonnes) went to landfill, 8\% was incinerated and 27\% was recycled (DEFRA 2010b). Demolition waste is also being recycled and now approximately half (about $42 \mathrm{M}$ tonnes in 2005) is reused (2010a). Prior to about 2000, most went into landfill sites. The volumes of waste deposited as artificial ground is difficult to determine due to the differing ways in which it has been classified. However, DEFRA figures show that from 1988-2008 the total amount of landfill material was about $800 \mathrm{M}$ tonnes, equivalent to about $0.8 \mathrm{~km}^{3}$ of material in ten years.

\section{Anthropogenic activity in the geological record: artificial ground classification and characterisation}

\subsection{Natural and Anthropogenic landscape evolution}

Human and natural processes rarely operate in temporal or spatial isolation. Anthropogenic processes contribute to the evolution of the landscape through the production of artificial ground, including archaeological remains. This includes areas where human activity has modified the landscape through removal or placement of rock, soil and waste material. The type of excavation and composition of anthropogenic material reflects the process that 
emplaced it and its origin. Its composition can be extremely variable both laterally and vertically, representing rapid land use change in one locality. Stratigraphically, artificial ground can be interpreted as sedimentary deposits or excavations representing the human geological record during the Anthropocene.

\subsection{Artificial Ground Classification}

It was not until the 1960s that artificial ground was shown on geological maps published by the BGS (British Geological Survey 1978), and not until the 1990s that artificial ground mapping became a routine aspect of geological surveying (British Geological Survey 1995; McMillan \& Powell 1999). Artificial ground is recognised as a potential ground hazard due to the variability of its composition, ground stability (including landslides) and its association with potentially contaminative land uses (Bishop 1973; Rosenbaum 2003). However, it also represents the 'geological' evidence for historical anthropogenic activity and forms part of the shallow zone of human interaction in the subsurface. Where socioeconomic conditions are suitable, some types of artificial ground may be a resource (former metalliferous waste tips for example). Artificial ground may also enhance ecosystems and the services they provide, for example through the creation of ecological habitats in areas of historical mineral extraction.

Artificial ground characterisation requires the identification of a diagnostic landform (morphology) and where possible its physical, sedimentological and lithological (compositional) characteristics (Rosenbaum et al. 2003). In general, a combination of these characteristics is required to interpret the genesis of artificial ground, though they may not always be available. For example, a landform may be well defined at the surface but its subsurface properties and thickness may be unknown. Conversely, subsurface data from boreholes and excavations may be available, but there may be no surface landform associated with it (Rosenbaum et al. 2003). Modern 1:10 000 and 1:50 000 scale British geological maps use a 5-fold classification scheme in their depiction of artificial ground (Table 2 and Figure 2). This artificial ground classification is based on a morpho-stratigraphic approach with an emphasis on the landform and the anthropogenic process that created it. In this scheme, Made Ground includes engineered fill. Landforms are identified through a combination of observation and the appraisal of spatial data sources, including aerial photographs, topographical maps, digital elevation models and ground investigation data (Figure 3). The combined use of recent spatial data and multiple generations of legacy data, allows historical land-use change to be considered and the most appropriate class of artificial ground to be chosen. However, with the exception of infilled ground, the scheme does not account for different phases of anthropogenic activity that may be represented at any one location.

In response to a continuing increase in the recognition of artificial ground as a key component of the human zone of interaction (Rosenbaum 2003; Walton \& Lee 2001), an enhanced classification scheme for artificial ground in 2D and 3D has been devised (Ford et al. 2006; Price et al. 2004). This extensible scheme is structured as a three-tier hierarchy, using Class, Type and Unit to describe in progressively more detail the origin and landform of the deposit or excavation (Figure 4). Where multiple sources or generations of artificial ground exist, the temporal and aerial extent from each source may be recorded to capture the development of the artificial ground as a factor in anthropogenic landscape evolution (Figure 5). Thematic surveys, including a detailed study of central Liverpool, have applied the enhanced scheme to develop an integrated anthropogenic and natural landscape evolution model (Figure 6 and Table 3). The scheme is designed to interface with complementary schemes including the National Land Use Database that contains information on previously developed land in England (Harrison 2006). Parallel schemes for the classification of urban 
soils offer the potential for further integration and the development of a comprehensive reference framework for urban environmental research (Hollis 1991). The enhanced artificial ground classification scheme provides a basis for the quantification of anthropogenic activity within the Anthropocene.

\subsection{Artificial Ground Distribution}

The gross distribution of mapped artificial ground in Great Britain is a function of the date when individual areas (1:50 000 scale geological map sheets) were last surveyed.

(Figure 7). Although geological data exists for almost every sheet, only those surveyed since the 1960s (approximately two thirds of Great Britain) show any significant artificial ground. Based on an assessment of available geological map data, approximately $1.4 \%$ of mainland Britain is covered by artificial ground (Table 4).

The extent of mapped artificial ground is greatest in urban conurbations where the landscape has been affected by frequent phases of human activity. For example, artificial ground covers almost $18 \%$ of the land in Manchester including colliery spoil, infilled brick and gravel pits, industrial waste and infilled river valleys (Burke et al. 2009). Rural areas, commonly the source of much of the material destined for accumulation in urban and industrial conurbations, show less than $1 \%$ artificial ground coverage. For example, artificial ground in Saxmundham in rural Suffolk, represents only $0.7 \%$ of the sample area, comprising infrastructure, coastal defences and mineral extraction sites that have provided aggregates for surrounding urban areas. Composite areas such as the Midland Valley of Scotland and the wider London area combine both the source and accumulation sites for artificial deposits and show an average coverage of approximately $7.2 \%$ by area.

The figures presented here for the extent of artificial ground are an underestimate of their probable total coverage. The limitations of conventional geological surveying and map production (scale restrictions and cartographic generalisation) result in an underrepresentation of artificial ground. Similarly, rapid land use change, especially in urban areas means that recent artificial ground may be unrecorded.

Recent advances in 3D geological modelling of the shallow subsurface has enabled the development of the 3D characterisation and classification of artificial ground. 3D geological modelling methodologies using GSI3D ${ }^{\mathrm{TM}}$ software (Kessler et al. 2009) have been applied to artificial ground to quantify and visualise anthropogenic landscape evolution in Manchester and Liverpool, NW England (Price et al. 2010). Coverage of 3D geological models in Great Britain is increasing but is not yet as extensive as 2D geological maps. Extending the 2D classification into 3D is an essential tool in characterising the legacy of anthropogenic impacts including concealed anthropogenic events in the subsurface. 3D geological models capture the vertical sequence and volume of individual deposits and excavations, providing a 3D framework for attribution with age and composition information. This is especially important in areas with specific historic activities that may be obscured beneath younger made ground or natural deposits. Figure 8 shows the thickness of made ground resulting from industrial land use change over approximately 160 years in Trafford Park, Salford in NW England. This is derived from a 3D geological model based on the interpretation of approximately 3600 boreholes for the area shown. The composition and thickness of made ground in this area is recorded in boreholes and this data is used to constrain the geological models. In Figure 8, made ground infilling the former course of the River Irwell and deposited adjacent to the Manchester Ship Canal is up to $10 \mathrm{~m}$ thick and comprises colliery spoil, furnace waste and ash probably deposited during construction of the canal in between 1887 and 1894. 
Artificial ground that is formed as a result of changing land use through time is commonly contaminated and is therefore a potential source of pollution. The land use history of a site or the area in which it lies strongly influences not only the type of artificial ground, but also its chemical properties. In some cases the anthropogenic chemical signatures of artificial ground, or the sediment into which the pollution may migrate, can be used as a marker for the source of contamination and its absolute age. Sediments recovered in the Mersey Estuary, NW England show distinct contamination with elevated concentrations of polycyclic aromatic hydrocarbons (PAHs), polychlorinated biphenyls (PCBs) and Mercury (Vane et al. 2007; Vane et al. 2009). These signatures, and their variation with depth, are interpreted to relate to the industrial development of the Mersey region where elevated mercury concentrations are associated with the expansion of the chemicals industry on the banks of the estuary in the mid $19^{\text {th }}$ century. It is possible to relate these chemical signatures to the timing of the onset of industrial processes and therefore provide an indicative age of the estuarine sediments and the related artificial ground source onshore. In other cases, methods of relative dating of artificial ground can be derived from historical map and written data sources. Dearman (1977) illustrated the relative anthropogenic history of infilling and culverting in part of the catchment of the rivers Tyne and Wear, NE England. Relative dating and recognition of anthropogenic markers in the anthropogenic stratigraphical record has also been achieved using distinctive objects in the subsurface. Ager, (1993) highlights one approach during the investigation of old mining camps in the USA, using the changing shape of beer cans as an 'evolutionary' marker. Ager also refers to a French classification system of anthropogenic deposits using such markers into an Upper dustbinian/trascanian (with plastic) and a Lower dustbinain/trascanian (without plastic).

The conventional BGS approach to mapping and 3D modelling of artificial ground does not explicitly describe its composition or attribute an age. However, lithological composition is an important factor in the characterisation of human geological signature in the Anthropocene. The degree of lateral and vertical heterogeneity in artificial deposits in the subsurface is assumed to be high. However, the composition of made ground and engineered fill can be characterised based on its texture, grain size and lithological composition (whether reworked rock or soil, or processed anthropogenic sediments). Both the grain-size and composition of the material can be recorded. Schemes such as British Standards for the description of soils and rocks can be used to describe anthropogenic material

(British Standards Institution 1999). For material deposited as waste, a classification based on that described in the European Waste Catalogue might be applied to compliment a description of the sediment (Environment Agency 2005).

The 2D and 3D classification and characterisation of artificial ground could be further enhanced by applying an attribute that describes the relative or absolute age of artificial ground to derive the rates of anthropogenically driven land use change.

\section{Preservation potential of anthropogenic artificial ground}

The classification and characterisation of artificial ground provides a means to quantify the magnitude of anthropogenic activity. However, in geological time, this is dependent on its subsurface preservation. The natural geological record represents a complex legacy of processes. At one extreme, processes of accumulation result in the localised building of the rock record and the preservation of evidence of geological events and environments (e.g. sediments and fossils). At the other extreme, processes of erosion result in the removal and reworking of existing deposits and the introduction of time gaps (discontinuities) in the rock record. The result is an incomplete and often biased perspective on the geological history of an area. Processes responsible for artificial ground operate in a similar fashion: human 
activity includes the accumulation of material (typically, but not exclusively in urban environments) and the widespread removal of both natural and existing artificial deposits. These processes operate alongside their natural equivalents. The preservation of artificial ground in the geological record is contingent on its ability to survive the erosive and transformative effects of both natural and human processes in terrestrial environments.

Artificial ground is predisposed for destruction. The most immediate threat to its preservation is that of changing land use in response to social and economic drivers including the regeneration of existing urban and industrial development and the exploitation of material previously classified as waste (e.g. reworking abandoned mine waste tips to exploit historic "waste” deposits (Collins \& Miller 1979; Scott et al. 2005) and landfill mining (van der Zee et al. 2004). In the longer term, most artificial ground will succumb to natural processes as erosion seeks to re-establish equilibrium that has been exceeded by the creation of artificial ground. Once buried, anthropogenic material in the ground is subject to chemical degradation. For organic deposits, hydrogeological conditions surrounding the material and changes in those conditions related to land use and environmental change may determine their susceptibility to degradation (Holden et al. 2009). Fluctuations in water level control the redox potential of the subsurface environment, promoting the formation of corrosive chemical species. Studies in the heritage city of York, UK have identified up to $8 \mathrm{~m}$ of waterlogged organic, anthropogenic deposits beneath the city. Dewatering and urban development have degraded the buried deposits in-situ, reducing their preservation potential.

However, it should be noted that when appropriate conditions prevail, the geological record has the potential to capture traces of fleeting events (Mazin et al. 2009; Shul'ga 2004) and remarkably delicate lifeforms (von Bitter et al. 2007; Wilkinson et al. 2010). Traces of anthropogenic activity dated to $3649 \pm 109$ BP comprising footprints and trackway infrastructure have been preserved on the coast of NW England (Gonzalez \& Cowell 2004) for example. The same may apply to the preservation of made ground and "habitation traces" such as buildings, landfill sites and engineered structures (Zalasiewicz 2008).

Specific locales, such as river valleys, have always held an attraction for the settlement of human communities. Analysis of the British fluvial stratigraphic record indicates a wider variety of channel types and styles in the past than found today, following the widespread and large scale land drainage and channelization that accompanied the Industrial Revolution (Howard \& Macklin 1999). Low energy river systems are accretional in nature and coupled with high water tables from c. 5000 to 4000BP and 2500BP which have influenced catchment hydrology, they have increased the likelihood of cultural deposit preservation (Howard \& Macklin 1999). Conversely, in some areas, construction and development in river valleys has led to drainage of valley floors, which has resulted in the lowering of water tables and the oxidation and subsequent degradation of archaeological deposits (Howard \& Macklin 1999). Whilst the accumulation of fine- grained sediments can improve the chances of preservation, it can also mask the deposits so that they cannot be detected by traditional prospection techniques. River valley environments can only be effectively studied by a multidisciplinary approach which seeks to integrate archaeological and geomorphological evidence (Howard \& Macklin 1999).

Although brick, concrete, steel, plastic and glass represent significant components of artificial deposits, their relative propensity for preservation varies considerably. A comprehensive account of the specific mechanisms affecting preservation potential is beyond the scope of this paper. In general however, the longer-term preservation potential for material deposited in terrestrial environments is far lower than that for marine environments. This presents a particular challenge for the preservation of artificial ground which is preferentially developed on land. Natural terrestrial processes including the weathering effects of wind and ice and the erosive potential of relatively high-energy fluvial systems 
conspire to level the land surface (conveying material to the marine environment). The proportion of marine strata (including coastal delta deposits) in the 3 billion year old bedrock geological record in Great Britain is almost 3 times that for strata deposited in a terrestrial environment (Great Britain's bedrock geology comprises approximately 57\% marine deposits and $20 \%$ terrestrial deposits with the balance of $23 \%$ represented by igneous or metamorphic strata).

It is therefore likely that artificial ground associated with coastal plain cities may have the greatest potential for preservation (Zalasiewicz 2008). In a scenario of rising sea-level, the process of preservation may begin with abandonment (and the cessation of potentially destructive human processes) followed by inundation (and the abeyance of terrestrial weathering) and the eventual concealment beneath natural marine deposits, offset by the process of coastal erosion. With increased depth of burial, the effects of heat and pressure may commit the artificial ground to the sedimentary cycle and bedrock record.

An appropriate timeframe is essential when considering the preservation potential of anthropogenic activity, from predicting its preservation in the context of geological time (and the concept of the Anthropocene), to understanding the nature of evidence for early human activity or potential contamination associated with recent made ground. The anticipated response of anthropogenic deposits and landforms to each of these time "scales" is an essential factor in understanding the legacy of human activity on the landscape.

\section{Conclusions}

Humans are a major factor in transforming the landscape, including the subsurface, through the deliberate shift of rock and soil, production of waste and enhanced denudation from agricultural activity. The physical transformation of the landscape correlates with increased population growth and the development of socioeconomic, political, technological and cultural drivers for landscape exploitation to meet their needs. The physical transformation can be measured in terms of its magnitude of impact (quantity of material moved) and its rate (the time over which the material movement occurred). Humans as geological and geomorphological agents are a major factor in British landscape evolution within the Anthropocene.

Rapid and large scale anthropogenic activity is commonly associated with the Industrial Revolution. The sedimentological consequences of this are coincident with atmospheric release of gases such as methane $(\mathrm{CH} 4)$ and carbon dioxide $\left(\mathrm{CO}_{2}\right)$ to the atmosphere. As such, the sedimentological response and its record in the subsurface can be considered a marker defining the Anthropocene and is broadly coincident with the Industrial Age of the Anthropocene proposed by (Steffen et al. 2007).The impacts of much earlier human activity as a landscape transforming agent in the Anthropocene should not be discounted however.

Anthropogenically driven landscape changes were already in place before the Industrial Revolution. The timing of the onset of humans as geological and geomorphological agents in Great Britain can be considered as that time in which earth moving activities began. The transformation from hunter gatherer to farming communities with small scale subsurface exploitation for flint occurred at Grimes Graves during the Neolithic and is one example of early human activity as a landscape transforming process through creation of artificial ground. The onset of Bronze Age resource exploitation, metal processing and agricultural activity on a larger geographic scale than previously seen represented a further transformation towards humans becoming significant factors in landscape evolution and a defining factor in the Anthropocene. 
As with geological boundaries, the timing of onset of major anthropogenic activity is likely to have been different across different areas in Great Britain. The nature of this difference is likely to be even greater on a global scale. Therefore the timing of significant anthropogenic activity as a geological and geomorphological process and its sedimentological impact is likely to be diachronous over tens, hundreds or even thousands of years when the developed and developing worlds are considered. The widespread exploitation of subsurface minerals, especially coal and iron in Great Britain, led to rapid transformation of the landscape as materials were excavated and waste deposited. Waste disposal, and large scale urbanization, may represent the most significant visible record of widespread human activity in Great Britain. This record may also be preserved in the subsurface geological record. Future uses of the subsurface such as repositories for disposal of radioactive wastes may also provide a mechanism for the preservation of underground artificial ground.

The characterisation of the drivers for anthropogenic processes, land use change and the resulting artificial ground is essential to quantify the impacts of historical and current anthropogenic activity on the geosphere. The interaction of people and the shallow subsurface creates a shallow zone of human interaction where natural and anthropogenic processes take place. The sustainable management of this zone and the ecosystem services to societies that it provides is critical if it is to function effectively in response to future environmental change. Its resilience to environmental change, including changes in land use, climate and population growth will determine its nature and properties within the Anthropocene Epoch.

\section{Acknowledgements}

The authors wish to acknowledge the assistance of colleagues and research partners including Hans de Beer (Geological Survey of Norway), Jan Zalaseiwicz (University of Leicester), Martin Culshaw (University of Birmingham), Don Cameron, Jo Mankelow and Teresa Brown (BGS), Laurance Donnelley and Dave Wilshaw (Wardell Armstrong). The helpful review comments of Helen Reeves and Helen Burke at the BGS, Andy Howard (University of Birmingham) and Ian Douglas (University of Manchester) are also gratefully acknowledged. John Powell, Dave Lowe, and Holger Kessler (BGS) are thanked for their contribution to the development of the classification schemes of artificial ground used in 3D geological models and on maps published by the British Geological Survey.

This article is published with the permission of the Executive Director of the British Geological Survey (NERC). 


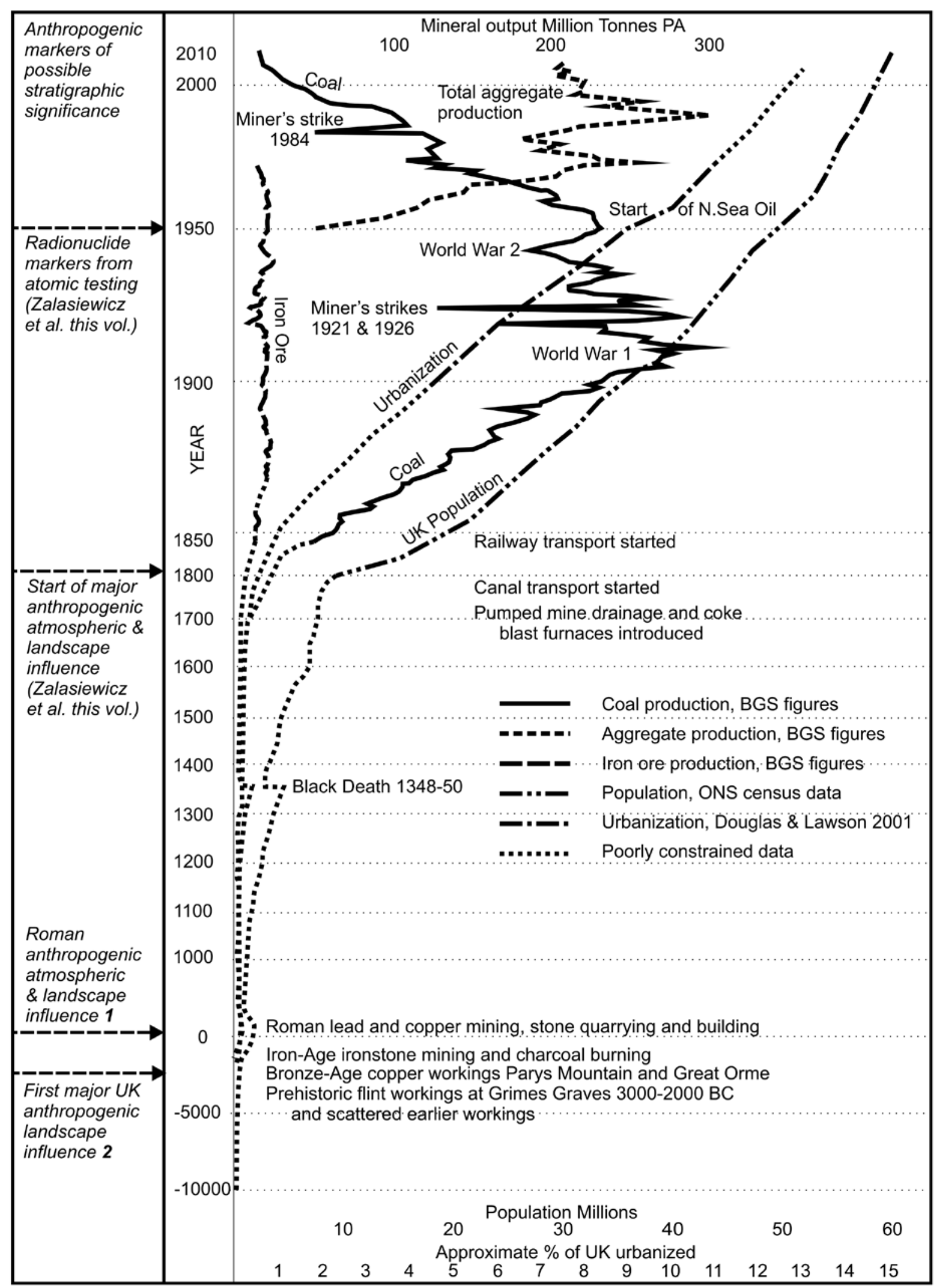

Figure 1. Possible stratigraphical markers in the Anthropocene based on use of UK-produced natural resources over time compared with population growth, urbanization and some major events and developments. Mineral production figures are from British Geological Survey (1973-2009) and precursor documents from 1853-1972 referred to in British Geological Survey (2009) page iv. Population figures are from the census data available on 
the internet and various graphs summarising this information. Urbanization is from Douglas \& Lawson (2001), extrapolated in line with population because the way urban land has been classified has changed and comparable figures are not available for recent years. ${ }^{1}$ Major town and city growth, centralisation, resource exploitation and waste generation, ${ }^{2}$ Generally localised but significant anthropogenic landscape modification beginning in the Neolithic.

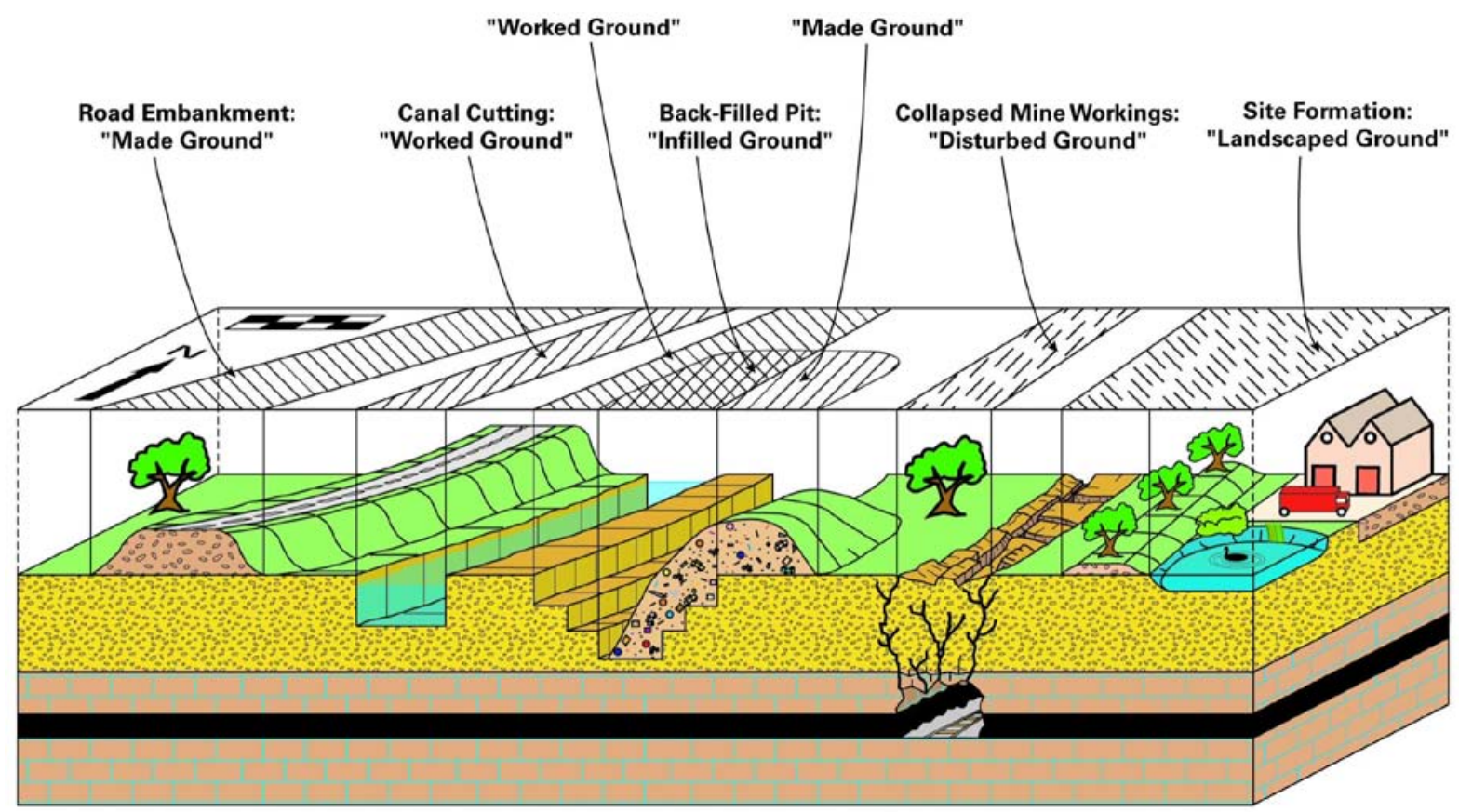

Figure 2. Examples of the main types of artificial ground and how they are shown on geological maps by the British Geological Survey (Ford et al. 2006; Price et al. 2004) 


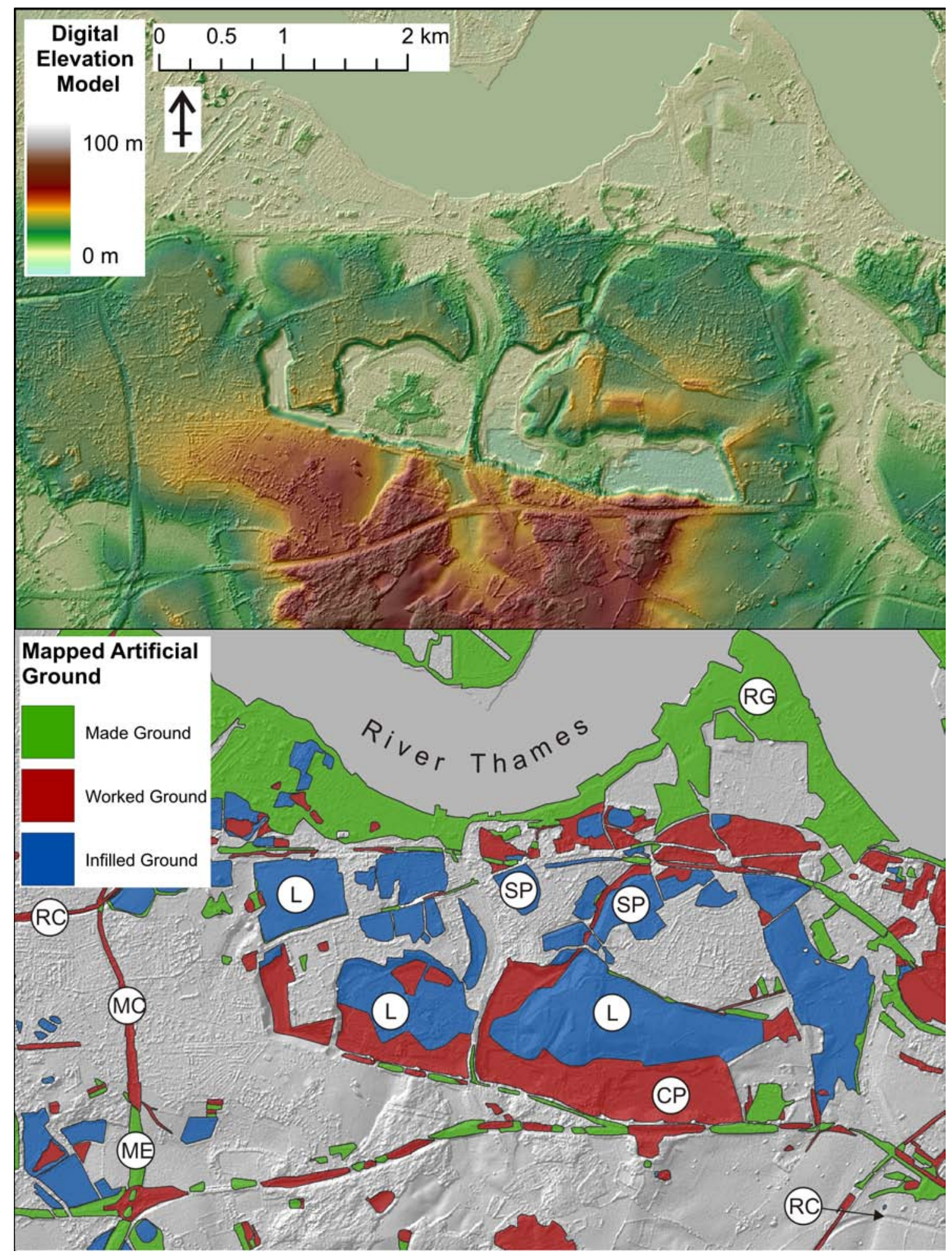

Figure 3. NEXTMap digital elevation model (top) and mapped distribution of artificial ground (bottom) for the Swanscombe area, east of London, UK. The impact of anthropogenic processes on the landscape reflects a complex legacy of mineral extraction, infrastructure development and waste management. The rapid evolution of the anthropogenic landscape is highlighted by differences between the mapped extent of artificial ground (c.1998) and the digital elevation model (2002-2005), including the Channel Tunnel Rail Link cutting (lower right) opened in 2003. $\mathrm{RC}=$ railway cutting, $\mathrm{MC}=$ motorway cutting, $\mathrm{ME}=$ motorway embankment, $\mathrm{L}=$ landfill site, $\mathrm{RG}=$ raised ground, $\mathrm{CP}=$ chalk pit, $\mathrm{SP}=$ sand and gravel pit. NEXTMap Britain elevation data from Intermap Technologies. DiGMapGB50 BGS @ NERC 


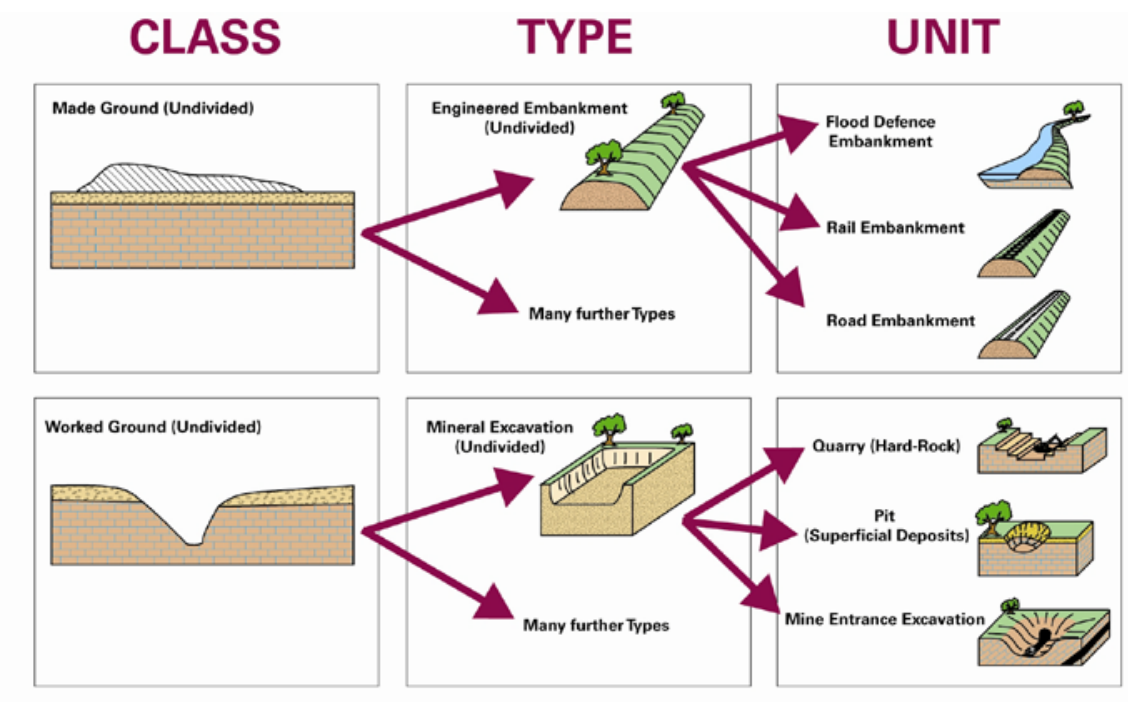

Figure 4. Example classification for made ground and worked ground in the enhanced classification scheme (Ford et al. 2006); many more types are present in the full scheme

\section{INFILLED GROUND EXAMPLE 1}

No detail known about 'cut' but detail known about 'fill'. For example, Worked Ground (Undivided) filled with Landfill WasteTip (Domestic Refuse)

\section{INFILLED GROUND EXAMPLE 2}

Detail known about 'cut' but no detail known about 'fill'. For example, Rail Cutting filled with Made Ground (Undivided)
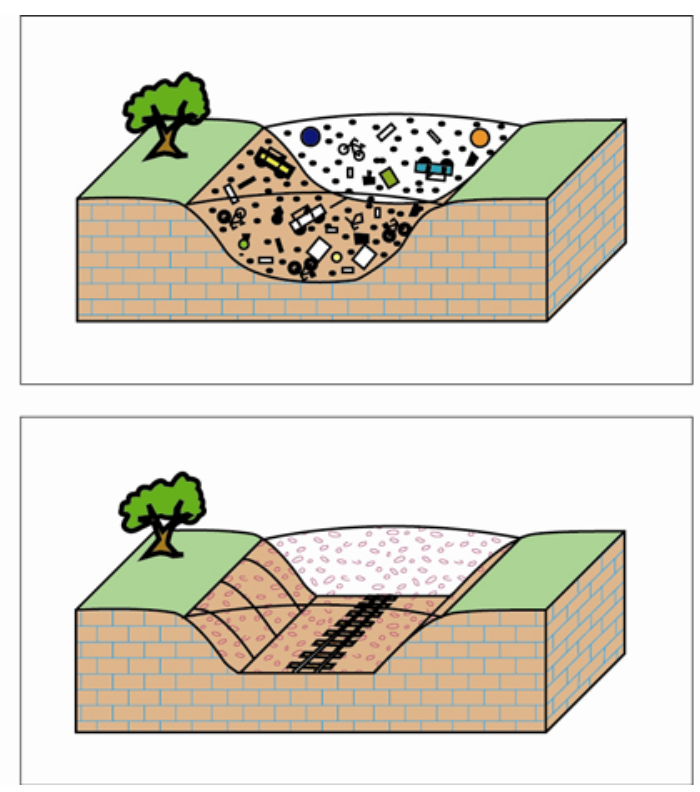

Figure 5. Example classification of Infilled Ground derived from the enhanced classification of Artificial Ground from Ford et al. (2006) 


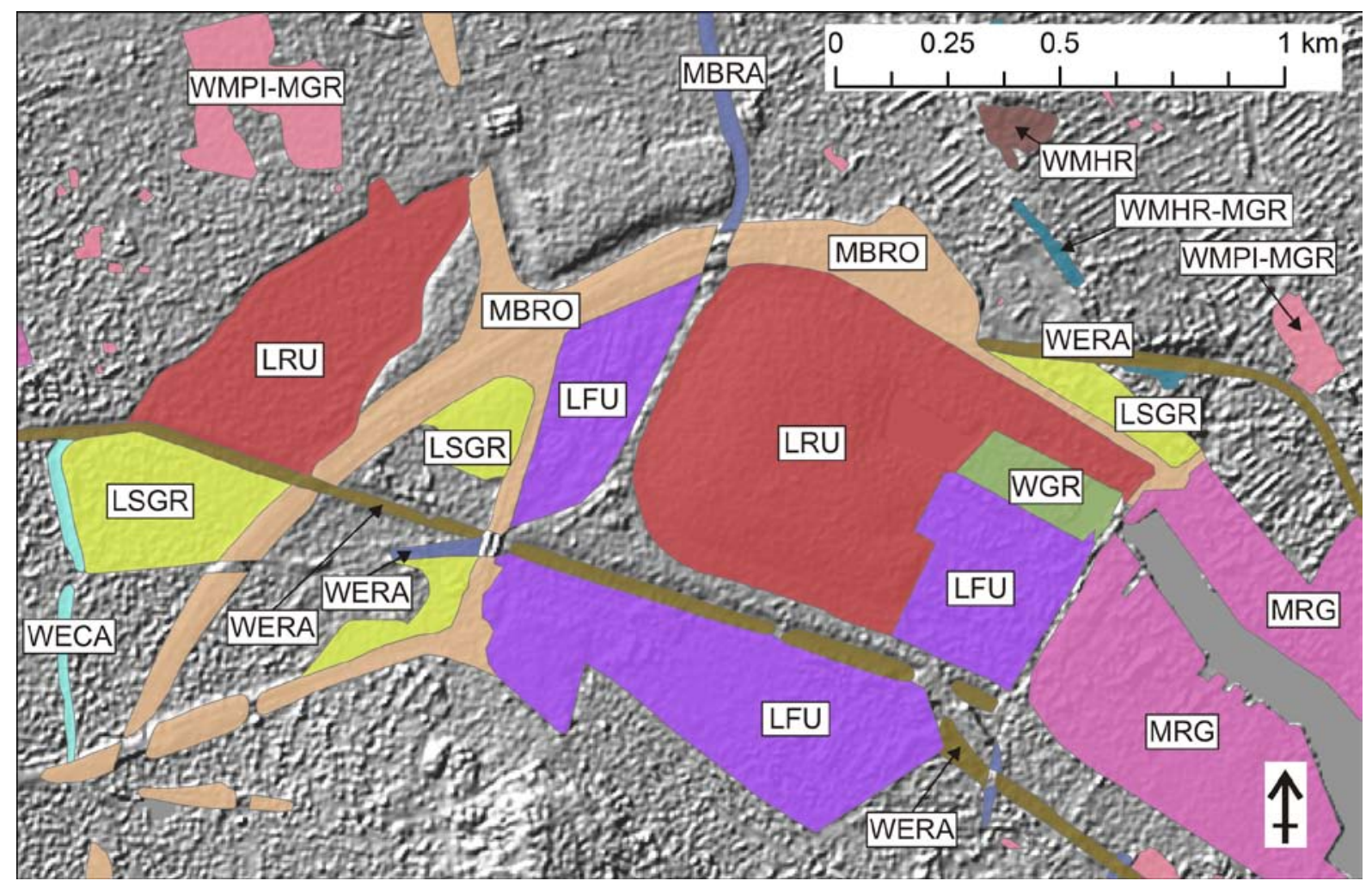

Figure 6. The mapped distribution of Artificial Ground in the Wallasey district of Liverpool, UK classified according to the enhanced classification scheme for artificial ground (see Table $\mathbf{3}$ for an explanation of the codes). NEXTMap Britain elevation data from Intermap Technologies. DiGMapGB50 BGS @ NERC 


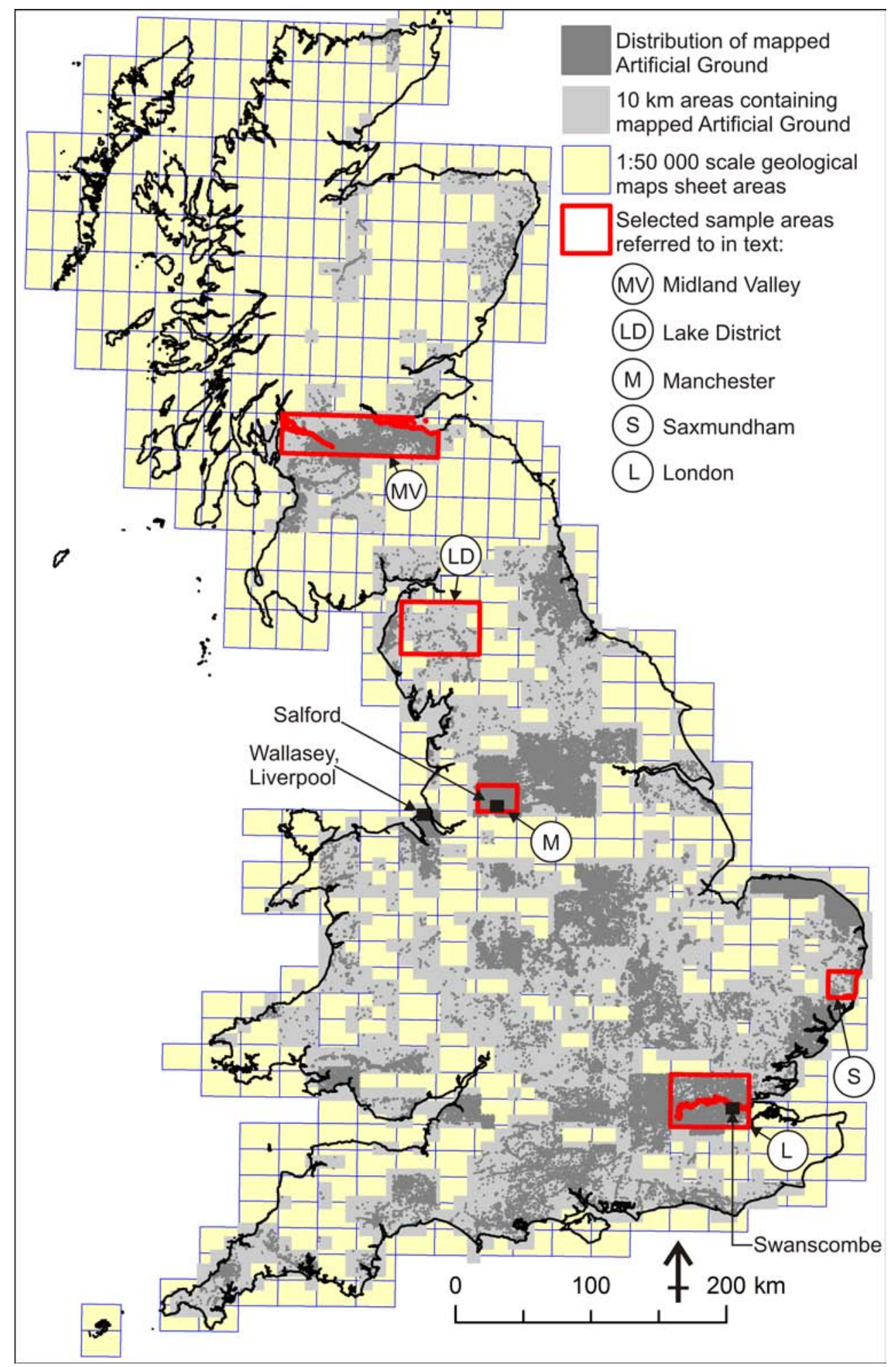

Figure 7. Map showing the distribution of artificial ground mapping in Great Britain. Individual areas of mapped artificial ground (dark grey) have been exaggerated for clarity. OS topography (C) Crown Copyright. All rights reserved. 100017897/2010 

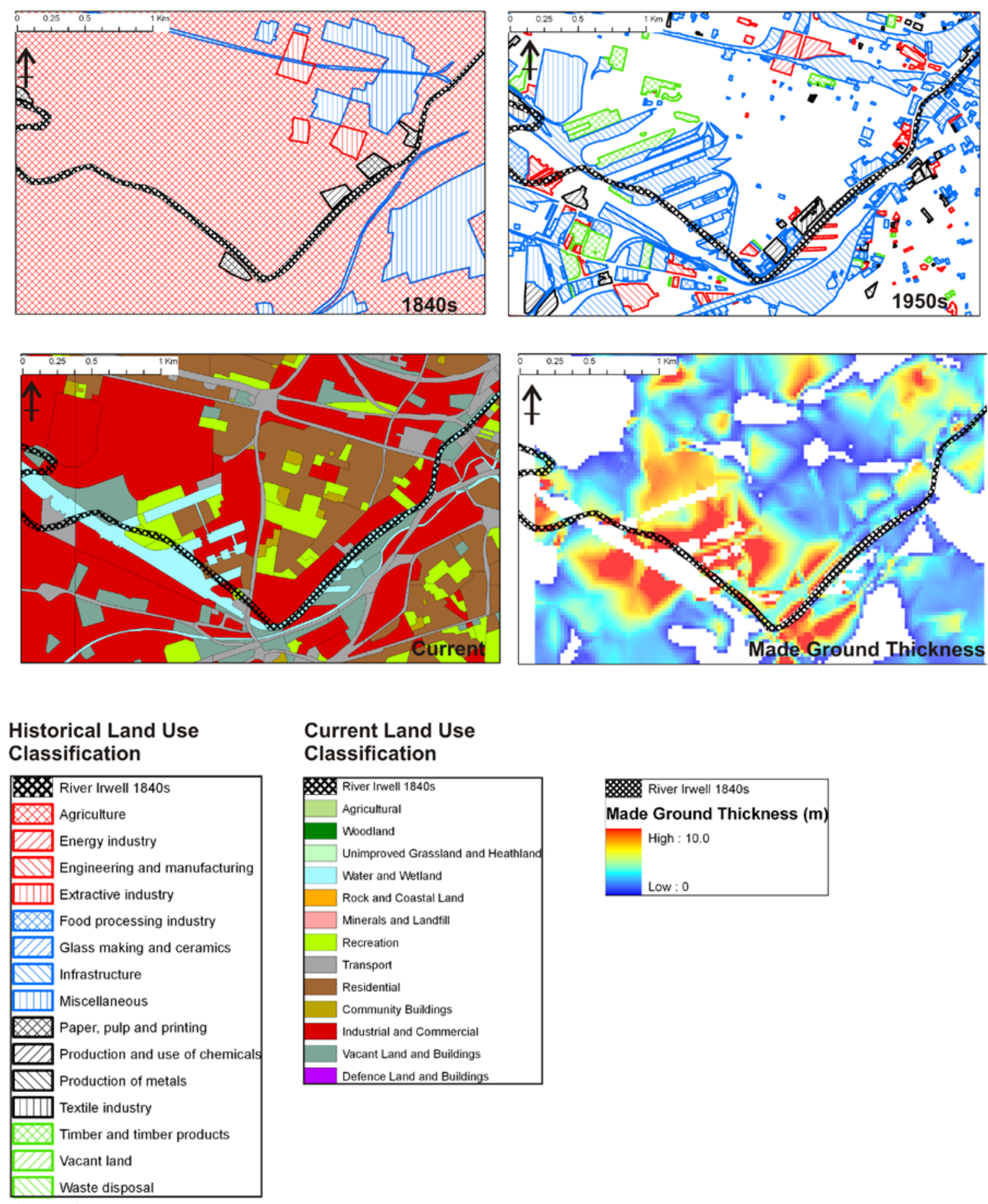

\section{Current Land Use Classification}

\begin{tabular}{l} 
River Irwell 1840s \\
Agricultural \\
Woodland \\
Unimproved Grassland and Heathland \\
Water and Wetland \\
Rock and Coastal Land \\
Minerals and Landfill \\
Recreation \\
Transport \\
Residential \\
Community Buildings \\
Industrial and Commercial \\
Vacant Land and Buildings \\
Defence Land and Buildings \\
\hline
\end{tabular}

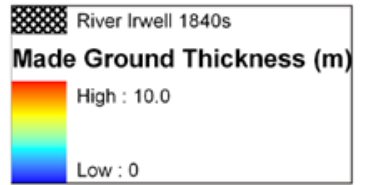

Figure 8: Land use change and resulting made ground thickness derived from a 3D geological model in a $\sim 160$ year period in Salford Quays, NW England. 2000s land use classification based on National Land Use Database Harrison (2006). Historical land use based on Department for the Environment (2000). OS topography @ Crown Copyright. All rights reserved. 100017897/2010 


\begin{tabular}{|c|c|c|}
\hline Period/Age (BP) & $\begin{array}{l}\text { Generic anthropogenic processes/ example } \\
\text { locations }\end{array}$ & $\begin{array}{l}\text { Relative geological and/or } \\
\text { geomorphological impact }\end{array}$ \\
\hline $\begin{array}{l}\text { Late Upper } \\
\text { Palaeolithic } \\
\sim 13000 \text { BC- } \\
\sim 8500 \text { BC }\end{array}$ & $\begin{array}{l}\text { Subsistence, hunter gatherer with earliest post } \\
\text { glacial human occupation of Great Britain } \\
\text { approximately } 13000 \text { years BP }\end{array}$ & Limited \\
\hline $\begin{array}{l}\text { Mesolithic } \\
\sim 8500 \text { BC- } \\
\sim 4000 \text { BC }\end{array}$ & $\begin{array}{l}\text { Subsistence hunter gatherer with small scale mobile } \\
\text { communities making forest clearings for dwellings } \\
\text { (e.g. Thatcham, Berkshire, UK) and transition to } \\
\text { longer lived periods of settlement (e.g. coastal shell } \\
\text { middens (domestic waste tips) at Oronsay in the } \\
\text { Hebrides) }\end{array}$ & $\begin{array}{l}\text { Localised with small scale tree } \\
\text { clearances and enhanced soil } \\
\text { erosion. Evidence from the } \\
\text { Yorkshire Wolds, UK suggests } \\
\text { localised anthropogenic activity } \\
\text { through tree clearance in 8900BP }\end{array}$ \\
\hline $\begin{array}{l}\text { Neolithic } \\
\sim 4000 \mathrm{BC}- \\
\sim 2600 \mathrm{BC}\end{array}$ & $\begin{array}{l}\text { Transition to agricultural communities and } \\
\text { domestication of crop and animal species. Industrial } \\
\text { activity in the form of construction of monuments, } \\
\text { including barrows using rock and soil, subsurface } \\
\text { working for flint in Grimes Graves, Norfolk, UK } \\
\text { hand axe production }\end{array}$ & $\begin{array}{l}\text { Locally high magnitude impact } \\
\text { through excavation and waste } \\
\text { production through mining } \\
\text { activity. Increased soil erosion } \\
\text { through agricultural activity and } \\
\text { tree clearance }\end{array}$ \\
\hline $\begin{array}{l}\text { Bronze Age } \\
\sim 2600 \mathrm{BC}- \\
\sim 800 \mathrm{BC}\end{array}$ & $\begin{array}{l}\text { Development of copper, bronze, tin and gold } \\
\text { metallurgy. Increased population settlement within } \\
\text { well defined boundaries. Continued agricultural } \\
\text { expansion and land division. Mineral extraction } \\
\text { (e.g. copper deposits of Great Orme and Parys } \\
\text { Mountain North Wales, UK) and earthwork } \\
\text { construction }\end{array}$ & $\begin{array}{l}\text { Local to widespread excavation } \\
\text { and processing of metal ores } \\
\text { Increased soil erosion through } \\
\text { agricultural activity (inc. tilling) } \\
\text { and tree clearance }\end{array}$ \\
\hline $\begin{array}{l}\text { Iron Age } \\
800 \mathrm{BC}-\mathrm{AD} 43\end{array}$ & $\begin{array}{l}\text { Settlement, agricultural land division, construction } \\
\text { of monuments, subsurface resource exploitation of } \\
\text { metal ores and charcoal burning (e.g. Great Orme, } \\
\text { North Wales, UK) }\end{array}$ & $\begin{array}{l}\text { Local to widespread excavation } \\
\text { and processing of metal ores } \\
\text { Increased soil erosion through } \\
\text { agricultural activity and tree } \\
\text { clearance }\end{array}$ \\
\hline $\begin{array}{l}\text { Roman } \\
\text { AD43-AD410 }\end{array}$ & $\begin{array}{l}\text { Settlement, construction engineering (inc. canals } \\
\text { and roads), agriculture, mineral extraction (inc. } \\
\text { lead, copper, tin, iron, brine and dimension stone), } \\
\text { pottery working }\end{array}$ & $\begin{array}{l}\text { Widespread mineral excavation } \\
\text { and waste production, metal ore } \\
\text { processing, urban growth, } \\
\text { subsidence and agriculture }\end{array}$ \\
\hline $\begin{array}{l}\text { Anglo- } \\
\text { Saxon/Scandinavi } \\
\text { an } \\
\text { AD410-AD1066 }\end{array}$ & $\begin{array}{l}\text { Fortified settlements (burhs) and monument } \\
\text { construction, urban growth (inc. York, Derby, } \\
\text { Nottingham and Leicester), pottery working, } \\
\text { industrial expansion including textiles, agriculture }\end{array}$ & $\begin{array}{l}\text { Widespread mineral excavation, } \\
\text { processing and waste production. } \\
\text { Agriculture }\end{array}$ \\
\hline $\begin{array}{l}\text { Medieval to } \\
\text { Industrial } \\
\text { Revolution } \\
\text { AD1066- } \\
\text { AD 1750 }\end{array}$ & $\begin{array}{l}\text { Urban expansion, industrial growth, technological } \\
\text { advance and widespread mineral exploitation (most } \\
\text { significantly; coal) increasing in intensity from the } \\
18^{\text {th }} \text { century }\end{array}$ & $\begin{array}{l}\text { Very widespread excavation, } \\
\text { processing and waste production. } \\
\text { Agriculture }\end{array}$ \\
\hline
\end{tabular}

Table 1. Pre-industrial (approximately pre $18^{\text {th }}$ Century) human interaction with the landscape including deliberate and unintentional (mainly agricultural) anthropogenic processes in Great Britain. Table compiled 
based on evidence from Bush, (1988); Goudie, (2000); Mithen, (1999); Pearson, (1999), Richards, (1999) and Roberts, (1998).

\begin{tabular}{|l|l|l|}
\hline $\begin{array}{l}\text { Artificial Ground } \\
\text { Class }\end{array}$ & Description & $\begin{array}{l}\text { Approximate percentage of total } \\
\text { mapped artificial ground in Mainland } \\
\text { GB }\end{array}$ \\
\hline Made ground & $\begin{array}{l}\text { Areas where material is known to have been } \\
\text { placed by humans on the pre-existing natural } \\
\text { land surface (including engineered fill) }\end{array}$ & $18.9 \%$ (equivalent to $1612 \mathrm{~km}^{2}$ ) \\
\hline Worked ground & $\begin{array}{l}\text { Areas where the pre-existing land surface is } \\
\text { known to have been excavated by humans }\end{array}$ & $54.2 \%$ (equivalent to $561 \mathrm{~km}^{2}$ ) \\
\hline Infilled ground & $\begin{array}{l}\text { Areas where the pre-existing land surface has } \\
\text { been excavated (Worked Ground) and } \\
\text { subsequently partially or wholly backfilled } \\
\text { (Made Ground) by humans }\end{array}$ & $23.4 \%$ (equivalent to $696 \mathrm{~km}^{2}$ ) \\
\hline Disturbed ground & $\begin{array}{l}\text { Areas of surface or near-surface mineral } \\
\text { workings where ill-defined excavations (Worked } \\
\text { Ground), areas of subsidence caused by the } \\
\text { workings and spoil (Made Ground) are } \\
\text { complexly associated with each other }\end{array}$ & $1.1 \%$ (equivalent to $32 \mathrm{~km}^{2}$ ) \\
\hline Landscaped ground & $\begin{array}{l}\text { Areas where the pre-existing land surface has } \\
\text { been extensively remodelled but where it is } \\
\text { impracticable to delineate separate areas of Made } \\
\text { Ground, Worked Ground or Disturbed Ground }\end{array}$ & $2.5 \%$ (equivalent to $73 \mathrm{~km}^{2}$ ) \\
\hline
\end{tabular}

Table 2. Artificial Ground classes shown by maps and 3D geological models produced by the British Geological Survey after Ford et al. (2006) 


\begin{tabular}{|llll|}
\hline Scheme Code & Class & Unit & Type \\
\hline WGR & Worked Ground & & \\
\hline WEU & Worked Ground & Engineered Excavation & Canal Cutting \\
\hline WECA & Worked Ground & Engineered Excavation & Artificial Pond /Lake \\
\hline WEML & Worked Ground & Engineered Excavation & Rail Cutting \\
\hline WERA & Worked Ground & Engineered Excavation & Road Cutting \\
\hline WERO & Worked Ground & Engineered Excavation & Quarry (Hard Rock) \\
\hline WMU & Worked Ground & Mineral Extraction & Pit (Superficial Deposit) \\
\hline WMHR & Worked Ground & Mineral Excavation & Flood Defence Embankment \\
\hline WMPI & Worked Ground & Mineral Excavation & Rail Embankment \\
\hline MGR & Made Ground & & Road Embankment \\
\hline MBFL & Made Ground & Engineered Embankment & Reservoir Embankment \\
\hline MBRA & Made Ground & Engineered Embankment & Screening Embankment \\
\hline MBRO & Made Ground & Engineered Embankment & Mine Waste Tip (Colliery) \\
\hline MBRV & Made Ground & Engineered Embankment & \\
\hline MBSR & Made Ground & Engineered Embankment & \\
\hline MWCY & Made Ground & Waste Tip & \\
\hline WGR-MGR & Infilled Ground (Undivided): Worked Ground (Undivided) and Made Ground (Undivided) \\
\hline WGR-MWCY & Infilled Ground: Worked Ground (Undivided) filled by Mine Waste Tip (Colliery) \\
\hline WMPI-MGR & Infilled Ground: Pit (Superficial Deposit) filled by Made Ground (Undivided) \\
\hline WPMI-MWCY Infilled Ground: Pit (Superficial Deposit) filled by Mine Waste Tip (Colliery) \\
\hline LSGR & Landscaped Ground & & \\
\hline LFU & Landscaped Ground & Landscaping For Site Formation & \\
\hline LRU & Landscaped Ground & $\begin{array}{l}\text { Landscaping For Recreational } \\
\text { Purposes }\end{array}$ & \\
\hline
\end{tabular}

Table 3. Selected entries from the enhanced classification scheme for artificial ground after Ford et al. (2006) including examples used in the characterisation of anthropogenic activity in Liverpool, UK. The maximum level of detail represented by each code is shown in italics 


\begin{tabular}{|c|c|c|c|c|}
\hline UK Location & $\begin{array}{l}\text { Sample } \\
\text { area }\left(\mathbf{k m}^{2}\right)\end{array}$ & $\begin{array}{l}\text { Mapped } \\
\text { artificial } \\
\text { ground area } \\
\left(\mathrm{km}^{2}\right)\end{array}$ & $\begin{array}{l}\text { Percentage } \\
\text { artificial ground } \\
\text { in sample area }\end{array}$ & $\begin{array}{l}\text { Principal sources of artificial } \\
\text { ground }\end{array}$ \\
\hline $\begin{array}{l}\text { Manchester city (large } \\
\text { industrial conurbation) }\end{array}$ & 559 & 99 & $17.8 \%$ & $\begin{array}{l}\text { Subsurface and open cast } \\
\text { mineral extraction, textiles and } \\
\text { engineering industrial } \\
\text { development, canals, } \\
\text { construction and demolition }\end{array}$ \\
\hline $\begin{array}{l}\text { London area (large } \\
\text { urban and peri-urban } \\
\text { conurbation with multiple } \\
\text { industrial centres) }\end{array}$ & 2196 & 181 & $8.2 \%$ & $\begin{array}{l}\text { Dockland development, open } \\
\text { cast mineral extraction, } \\
\text { commercial development, } \\
\text { construction and demolition }\end{array}$ \\
\hline $\begin{array}{l}\text { Midland Valley of } \\
\text { Scotland (rural with } \\
\text { multiple urban and } \\
\text { industrial centres) }\end{array}$ & 2297 & 185 & $6.2 \%$ & $\begin{array}{l}\text { Coastal industrial development, } \\
\text { opencast and subsurface } \\
\text { mineral extraction, metal } \\
\text { processing }\end{array}$ \\
\hline $\begin{array}{l}\text { Saxmundham, Suffolk } \\
\text { (rural lowland) }\end{array}$ & 394 & 2.8 & $0.7 \%$ & $\begin{array}{l}\text { Infrastructure, mineral } \\
\text { extraction, coastal defences }\end{array}$ \\
\hline $\begin{array}{l}\text { Lake District of } \\
\text { England (rural upland) }\end{array}$ & 2236 & 7.9 & $0.4 \%$ & Mineral spoil and infrastructure \\
\hline Mainland Great Britain & $\begin{array}{l}218478 \\
\left(129000^{2}\right)\end{array}$ & 2974 & $1.4 \%^{1}\left(2.3 \%^{2}\right)$ & $\begin{array}{l}\text { Mineral extraction, landfill, } \\
\text { infrastructure }\end{array}$ \\
\hline
\end{tabular}

Table 4. Summary of artificial ground in a range of "domains" throughout Great Britain based on 1:50 000 scale geological map sheet areas and the maximum coverage of artificial ground shown by BGS DiGMapGB10 10000 maps ( ${ }^{1}$ minimum figure due to incomplete coverage of artificial ground on geological maps. ${ }^{2}$ equivalent figures based on a regular grid of $10 \mathrm{~km}$ side length, considering only those cells that contain artificial ground) 
References

Ager, D. V. 1993 The nature of the Stratigraphical record: John Wiley \& Sons.

Bell, F., Stacey, T R, Genske, D D 2000 Mining subsidence and its effect on the environment: some differing examples. Environmental Geology 40, 135-152.

Bell, F. G., Stacey, T. R. \& Genske, D. D. 2000 Mining subsidence and its effect on the environment: some differing examples. Environmental Geology 40, 135-152.

Bishop, A. W. 1973 The stability of tips and spoil heaps. Quarterly Journal of Engineering Geology and Hydrogeology 6, 335 - 376.

British Geological Survey. 1978 Sunderland, vol. England and Wales sheet 21. Southampton: Ordnance Survey for the Institute of Geological Sciences.

British Geological Survey. 1973-2009 United Kingdom Minerals Yearbook: annual publications for 1973-2008. Keyworth, Nottingham: British Geological Survey.

British Geological Survey. 1995 Specification for the preparation of 1:10 000 scale geological maps (2nd edition). In British Geological Survey Technical Report vol. WA/95/64. Keyworth, Nottingham: British Geological Survey.

British Geological Survey. 2009 United Kingdom Minerals Yearbook 2008. Keyworth: British Geological Survey.

British Standards Institution. 1999 Code of practice for site investigations. BS 5930. London: British Standards Institution.

Burke, H. F., Price, S. J., Crofts, R. G., Thorpe, S. \& Terrington, R. L. 2009 The 3D representation of human impacts on the urban landscape, NW England. In 7th International Conference on Geomorphology. Melbourne, Australia.

Bush, M. B. 1988 Early Mesolithic disturbance: a force on the landscape. Journal of Archaeological Science 15, 453-462.

Carver, M. 1987 Underneath English towns. Interpreting urban archaeology. London: B T Batsford Ltd.

Collins, R. J. \& Miller, R. H. 1979 Utilization of mining and mineral processing wastes in the United States. Environmental Geochemistry and Health 1, 8-19.

Cooper, A. 2002 Halite karst geohazards (natural and man-made) in the United Kingdom. Environmental Geology 42, 505-512.

CrossRail. 2010 Crossrail will move five million tonnes of earth via river, vol. 2010.

Darwin, C. 1882 The formation of vegetable mould through the action of worms with observations on their habits. London: John Murray.

Dearman, W. R., Money, M. S., Coffey, J. R., Scott, P. \& Wheeler, M. 1977 Engineering geological mapping of the Tyne and Wear conurbation, North-East England. Engineering Geology 10, 145-168.

DEFRA. 2010a Sustainable consumption and production: 18. Waste: Department for Environment, Food and Rural Affairs.

DEFRA. 2010b UK Municipal waste management 2005/6: Department for Environment, Food and Rural Affairs.

Department for the Environment. 2000 Potential Contaminants for the Assessment of Land. London: Department of the Environment, Transport and the Regions.

Douglas, I. \& Lawson, N. 2001 The Human Dimensions of Geomorphological Work in Britain. Journal of Industrial Ecology 4, 9-33.

DTI. 2004 UK coal resource for new exploitation technologies.: Department for Trade and Industry

Durham Mining Museum. 2010.

Environment Agency. 2005 Hazardous Waste. Interpretation of the definition and classification of hazardous waste. Second Edition, Version 2.2, vol. Appendix 1.

Ford, J. R., Kessler, H., Cooper, A. H., Price, S. J. \& Humpage, A. J. 2006 An enhanced classification for artificial ground. In British Geological Survey Internal Report (IR/04/038): British Geological Survey.

Gonzalez, S. \& Cowell, R. 2004 Formby Point foreshore, Merseyside: Palaeoenvironment and Archaeology. In The Quaternary of the Isle of Man and North West England Field Guide (ed. 
R. C. Chiverrell, A. J. Plater \& G. S. P. Thomas), pp. 206-216. London: Quaternary Research Association.

Goudie, A. 2000 The human impact on the Natural Environment. Oxford: Blackwell.

Harrison, A. R. 2006 National Land Use Database: Land Use and Land Cover Classification: Office of the Deputy Prime Minister.

Haselgrove, C. 1999 The Iron Age. In The Archaeology of Britain. An introduction from the Upper Palaelithic to the Industrial Revolution (ed. J. Hunter \& I. Ralston), pp. 113-134: Routledge.

Holden, J., Howard, A. J., West, L. J., Maxfield, E., Panter, I. \& Oxley, J. 2009 A critical review of hydrological data collection for assessing preservation risk for urban waterlogged archaeology: A case study from the City of York, UK. Journal of Environmental Management 90, 3197-3204.

Hollis, J. M. 1991 The classification of soils in urban areas. In Soils in the urban environment (ed. P. Bullock \& B. J. Gregory), pp. 5 - 27. Oxford: Blackwell Scientific Publications.

Hooke, R. L. 2000 On the history of humans as geomorphic agents. Geology 28, 843-846.

Howard, A. J. \& Macklin, M. G. 1999 A generic geomorphological approach to archaeological interpretation in British river valleys: a guide for archaeologists investigating Holocene landscapes. Antiquity 73, 527-541.

Hudson-Edwards, K., A. 1999 Medieval lead pollution in the River Ouse at York, England. Journal of Archaeological Science 26/7, 809-819.

Jeffries, J. 2005 The UK population: past, present and future. In Focus On People and Migration, pp. 18: Office for National Statistics.

Kessler, H., Mathers, S. \& Sobisch, H.-G. 2009 The capture and dissemination of integrated 3D geospatial knowledge at the British Geological Survey using GSI3D software and methodology. Computers \& Geosciences 35, 1311-1321.

Mazin, J. M., Billon-Bruyat, J. P. \& Padian, K. 2009 First record of a pterosaur landing trackway. Proceedings of the Royal Society B-Biological Sciences 276, 3881-3886.

McMillan, A. A. \& Powell, J. H. 1999 BGS Rock classification scheme. Volume 4, classification of artificial (man-made) ground and natural superficial deposits: applications to geological maps and datasets in the UK: British Geological Survey.

Mithen, S. 1999 Hunter-Gatherers of the Mesolithic. In The Archaeology of Britain. An introduction from the Upper Palaeolithic to the Industrial Revolution (ed. J. Hunter \& I. Ralston), pp. 3557: Routledge.

Morgan, R. P. C. 1985 Assessment of soil erosion risk in England and Wales. Soil Use and Management 1, 127-131.

Mulder, E. F. J. d. 1996 Urban Geoscience. In Urban Geoscience (ed. G. J. H. McCall, E. F. J. d. Mulder \& B. R. Marker), pp. 1-11. Rotterdam: A A Balkema/Rotterdam/Brookfield.

NCB. 1975 Subsidence Engineers' Handbook: National Coal Board Mining Department.

Oakley, K. P. 1972 Man the Tool-maker. Trustees of the British Museum (Natural History). London.

Parys Underground Group. 2010 History of Parys and Mona copper mines, vol. 2010.

Pearson, M. P. 1999 The Earlier Bronze Age. In The Archaeology of Britain. An introduction from the Upper Palaeolithic to the Industrial Revolution (ed. J. Hunter \& I. Ralston), pp. 77-94: Routledge.

Pimental, D., Harvey, C., Resosudarmo, P., Sinclair, K., Kurz, D., McNair, M., Crist, S., Shpritz, L., Fitton, L., Saffouri, R. \& Blair, R. 1995 Environmental and Economic Costs of Soil Erosion and Conservation Benefits. Science 267, 1117-1123.

Pimental, D. \& Skidmore, E. L. 1999 Rates of soils erosion. Letters. Science 286, 1477.

Price, S., Ford, J., Kessler, H., Cooper, A. \& Humpage, A. 2004 Mapping our impact on the surface of the Earth. Earthwise 20, 30-31.

Price, S. J., Burke, H. F., Terrington, R. L., Reeves, H. J., Boon, D. \& Scheib, A. J. 2010 The 3D characterisation of the zone of human interaction and the sustainable use of underground space in urban and peri-urban environments: case studies from the UK. Zeitschrift der Deutschen Gesellschaft für Geowissenschaften (ZDGG) 161, 219-235.

Richards, J. D. 1999 The Scandanavian Perspective. In The Archaeology of Britain. An introduction from the Upper Palaeolithic to the Industrial Revolution (ed. J. Hunter \& I. Ralston), pp. 194209: Routledge. 
Roberts, N. 1998 The Holocene. Oxford: Blackwell.

Rosenbaum, M. S. 2003 Characterisation of the subsurface: implications for urban infrastructure and environmental assessments. In New paradigms in subsurface prediction: characterisation of the shallow subsurface: implications for urban infrastructure and environmental assessment (ed. M. S. Rosenbaum \& A. K. turner), pp. 3-6. Dusseldorf: Springer-Verlag.

Rosenbaum, M. S., McMillan, A. A., Powell, J. H., Cooper, A. H., Culshaw, M. G. \& Northmore, K. J. 2003 Classification of artificial (man-made) ground. Engineering Geology 69, 399-409.

Scott, P. W., Eyre, J. M., Harrison, D. J. \& Bloodworth, A. J. 2005 Markets for industrial mineral products from mining waste. Geological Society, London, Special Publications 250, 47-59.

Sherlock, R. L. 1922 Man as a geological agent; an account of his action on inanimate nature: H F \& G Witherby.

Shul'ga, V. F. 2004 Carboniferous Raindrop Imprints at the Southwestern Margin of the East European Platform. Lithology and Mineral Resources 39, 382-387.

Steffen, W., Crutzen, P. J. \& McNeill, J. 2007 The Anthropocene: Are Humans Now Overwhelming the Great Forces of Nature? Ambio 36, 614-621.

The Motorway Archive. 2010, vol. 2010.

Thomas, J. 2001 The archaeology of place and landscape. In Archaeological Theory Today (ed. I. Hodder), pp. 165-186. Cambridge: Polity Press.

van der Zee, D. J., Achterkamp, M. C. \& Visser, B. J. d. 2004 Assessing the market opportunities of landfill mining Waste Management 24, 795-894.

Vane, C. H., Harrison, I. \& Kim, A. W. 2007 Polycyclic aromatic hydrocarbons (PAHs) and polychlorinated biphenyls (PCBs) in sediments from the Mersey Estuary, UK. Science of the Total Environment 374, 112-126.

Vane, C. H., Jones, D. G. \& Lister, T. R. 2009 Mercury contamination in surface sediments and sediment cores of the Mersey Estuary, UK. Marine Pollution Bulletin 58, 928-946.

von Bitter, P. H., Purnell, M. A., Tetrault, D. K. \& Stott, C. A. 2007 Eramosa Lagerstätte exceptionally preserved soft-bodied biotas with shallow-marine shelly and bioturbating organisms (Silurian, Ontario, Canada). Geology 35, 879 - 882.

Walton, G. \& Lee, M. K. 2001 Geology for our diverse economy. In Report of the Programme Development Group for Onshore Geological Surveys. Keyworth, Nottingham: British Geological Survey.

Waters, C. N., Price, S. J., Davies, J., Tye, A. M., Brown, S. E. \& Schofield, D. I. 2005 Urban geology of Swansea-Neath-Port-Talbot. In Urban Geology in Wales, vol. Volume 2 (ed. M. G. Bassett, V. K. Deisler \& D. Nichol), pp. 7-22.

Wilkinson, B. H. 2005 Humans as geologic agents: A deep-time perspective. Geology 33, 161-164.

Wilkinson, I. P., Wilby, P. R., Williams, M., Siveter, D. J., Page, A. A., Leggitt, L. \& Riley, D. A. 2010 Exceptionally preserved ostracodes from a Middle Miocene palaeolake, California, USA. Journal of the Geological Society 167, 817-825.

Williams, C. J. 1995 A history of the Great Orme Mines from the Bronze Age to the Victorian Age. British Mining 52, 57.

Wilson, A. 2002 Machines, power and the ancient economy. Journal of Roman Studies 92, 1-32.

Zalasiewicz, J. 2008 The Earth After Us. What legacy will humans leave in the rocks?: Oxford University Press.

Zalasiewicz, J., Williams, M., Smith, A., Barry, T. L., Coe, A. L., Bown, P. R., Brenchley, P., Cantrill, D., Gale, A., Gibbard, P., Gregory, F. J., Hounslow, M., Kerr, A. C., Pearson, P., Knox, R., powell, J., Waters, C., Marshall, J., Oates, M., Rawson, P. \& Stone, P. 2008 Are we now living in the Anthropocene? Geological Society of America Today 18, 4-8.

Zalasiewicz, J., Williams, M., Steffen, W. \& Crutzen, P. 2010 The New World of the Anthropocene. Environmental Science and Technology 44, 2228-2231. 